\title{
RESORBABLE EXTRACELLULAR MATRIX GRAFTS IN UROLOGIC RECONSTRUCTION
}

\author{
RICHARD A. SANTUCCI, THEODORE D. BARBER \\ Wayne State University School of Medicine, Detroit, Michigan, USA
}

\begin{abstract}
Purpose: There is an increasingly large body of literature concerning tissue-engineering products that may be used in urology. Some of these are quite complex (such as multilayer patient-specific cell-seeded implants) yet the most simple and successful products to date are also the most uncomplicated: resorbable acellular extra-cellular matrices (ECMs) harvested from animals. ECMs have been used in a variety of difficult urologic reconstruction problems, and this review is intended to summarize this complex literature for the practicing urologist.

Methods: Medline search of related terms such as "SIS, small intestinal submucosa, ECM, extracellular matrix, acellular matrix and urologic reconstruction". Manuscripts missed in the initial search were taken from the bibliographies of the primary references.

Results: Full review of potential clinical uses of resorbable extra-cellular matrices in urologic reconstruction.

Conclusions: Currently, the "state of the art" in tissue engineering solutions for urologic reconstruction means resorbable acellular xenograft matrices. They show promise when used as a pubovaginal sling or extra bolstering layers in ureteral or urethral repairs, although recent problems with inflammation following 8-ply pubovaginal sling use and failures after 1- and 4-ply SIS repair of Peyronie's disease underscore the need for research before wide adoption. Preliminary data is mixed concerning the potential for ECM urethral patch graft, and more data is needed before extended uses such as bladder augmentation and ureteral replacement are contemplated. The distant future of ECMs in urology likely will include cell-seeded grafts with the eventual hope of producing "off the shelf" replacement materials. Until that day arrives, ECMs only fulfill some of the requirements for the reconstructive urologist.
\end{abstract}

Key words: reconstructive surgical procedures; small intestine; intestinal mucosa; extracellular matrix; grafts

Int Braz J Urol. 2005; 31: 192-203

\section{INTRODUCTION}

The future of tissue engineering promises nothing less than the manufacture of human replacement parts. However, the current reality is that true "replacement part" technology is likely years away, and we must continue to make good with what we have on hand to do urological reconstruction. To this end, resorbable extra-cellular matrix (ECM) graft technology has been validated in animal trials and is showing promise in early human clinical work. ECMs are de-cellularized sheets of tissues harvested from donor animals. The most studied of these is "small intestinal submucosa" or SIS, which is commercially available in several configurations (Surgisis ${ }^{\mathrm{TM}}$, Stratasis $^{\mathrm{TM}}$, and Stratasis-ESTM, Cook, Spencer, Indiana, USA). This sterile, freeze-dried, non-permanent, acellular matrix graft made from the jejunum 
of pigs appears to promote the rapid ingrowth of surrounding tissue. Other materials have been reported experimentally but not commercially, and still other ECMs are commercially available but are permanent so they differ substantially from ECMs such as SIS (Table-1). The goal of this manuscript is to review the functional characteristics of resorbable graft materials, so that the practicing urologist can understand their potential use in clinical practice.

\section{BENEFITS OF ECM}

The modern era of ECM started in the 1980s when SIS was used successfully as a large vessel re- placement graft in animals (1). The success with these grafts prompted further research and experimental data shows applicability in a variety of animal models: abdominal wall (rodents and dogs), blood vessels (dogs), tendon (dogs), skin (rats), dura (rats and dogs) and diaphragm (rats). SIS can support growth of keratinocytes, endothelial cells, smooth muscle cells and bone cells in vitro (2). The potential benefit of ECM is that it recapitulates the tissue it is meant to replace, a process that has been named "smart remodeling" (2).

Of special note to the urologist is that much animal work using ECM has concentrated on the bladder, urethra and ureter (see SURGICAL USES, below).

Table 1 - Comparison of various commercial and experimental ECMs.

\begin{tabular}{|c|c|c|c|c|c|}
\hline & & Resorbable & Source & Uses & $\begin{array}{l}\text { Currently } \\
\text { Available? }\end{array}$ \\
\hline $\mathrm{SIS}^{\mathrm{TM}}$ & Cook Urological & Yes & $\begin{array}{l}\text { Porcine small } \\
\text { intestine }\end{array}$ & $\begin{array}{l}\text { Multiple, "intelli- } \\
\text { gent remodeling" }\end{array}$ & Yes \\
\hline $\begin{array}{l}\text { FortaGen }^{\mathrm{TM}}, \\
\text { FortaPerm }^{\mathrm{TM}}\end{array}$ & Organogenesis & Partially & $\begin{array}{l}\text { Porcine small } \\
\text { intestine }\end{array}$ & $\begin{array}{l}\text { Support such as } \\
\text { sling, possible re- } \\
\text { placement via "intel- } \\
\text { ligent remodeling" }\end{array}$ & No \\
\hline Repliform $^{\mathrm{TM}}$ & $\begin{array}{l}\text { Lifecell, mar- } \\
\text { keted by Bos- } \\
\text { ton Scientific- } \\
\text { Microvasive }\end{array}$ & No & $\begin{array}{l}\text { Human } \\
\text { dermis }\end{array}$ & Pubovaginal sling & Yes \\
\hline $\begin{array}{l}\text { Pelvicol }^{\mathrm{TM}} \\
\text { (Permacol }^{\mathrm{TM}} \\
\text { in the UK) }\end{array}$ & Bard & Partially & $\begin{array}{l}\text { Porcine } \\
\text { dermis }\end{array}$ & Pubovaginal sling & Yes \\
\hline $\begin{array}{l}\text { Acell Urinary } \\
\text { Bladder } \\
\text { Submucosa } \\
\text { (UBS) }\end{array}$ & Acell & Yes & $\begin{array}{l}\text { Porcine } \\
\text { bladder }\end{array}$ & $\begin{array}{l}\text { Veterinary only at } \\
\text { this time (possibly } \\
\text { multiple via "intelli- } \\
\text { gent remodeling") }\end{array}$ & No \\
\hline $\begin{array}{l}\text { Acellular } \\
\text { Matrix Grafts }\end{array}$ & Experimental & Yes & $\begin{array}{l}\text { Various hu- } \\
\text { man (bladder, } \\
\text { urethra) }\end{array}$ & $\begin{array}{l}\text { Multiple, "intelli- } \\
\text { gent remodeling" }\end{array}$ & No \\
\hline Tutogen $^{\mathrm{TM}}$ & Tutogen & No & $\begin{array}{l}\text { Bovine peri- } \\
\text { cardium }\end{array}$ & Peyronie's repair & Yes \\
\hline
\end{tabular}


In humans, SIS has been used in several settings: as a urethral stricture onlay graft (3); as a pubovaginal sling (4); to repair Peyronie's disease (5); and to bolster partial nephrectomy closures (6). It is perhaps the bestvalidated graft material in use, although much clinical work must still be done. Pelvicol ${ }^{\mathrm{TM}}$ (sold as Permacol ${ }^{\mathrm{TM}}$ in Europe; Bard) acellular porcine dermis is also well researched. It has been used in over 60 different surgical procedures, such as abdominal wall defect repair, augmentation cystoplasty (7), pubovaginal slings (8), repair of Peyronie's disease (9) and augmentation phalloplasty (10).

\section{REPLACEMENT OF ECM GRAFT WITH TARGET TISSUE}

\section{ECM is Completely Absorbed}

The first characteristic of most ECMs that are not cross-linked (SIS, experimentally produced AMG, and Acell UBS) is its tendency to become almost completely absorbed following implantation. The graft is gradually replaced by local tissue ingrowth and is eventually no longer needed. It is histologically absent by day 28 in studies using both the dog bladder and mouse muscle (11), $90 \%$ absent by 60 days when used to replace the dog aorta, and $90 \%$ absent from the dog bladder within 3 months using a radiolabelling technique.

\section{ECM Promotes Avid Cell Ingrowth}

The second benefit of ECM is its tendency to support cell ingrowth, in part by potentiating native cell-cell interactions (12), and in part by providing structural support and the necessary extra-cellular proteins for tissue ingrowth. Over time, the graft is replaced by local tissue; grafts placed into the ureter (13) or bladder, for example, have been shown to grow a normal endothelial cell layer, smooth muscle, blood vessels, and nerves (Figure-1) (although the demonstration of nerve functionality in large animals or humans is yet to be seen). In a study of SIS in a rat bladder, the grafts re-grew contractile, functioning bladder with muscarinic, purogenic, and $\beta$-adrenergic receptors (14).

One of the reasons ECM allows cell ingrowth is that it is composed mostly of matrix pro- teins, which have powerful abilities to promote and direct the ingrowth of various cell types. SIS, for example, is made up of $90 \%$ Type I and Type IV collagen, which can promote endothelial cell adhesion and growth $(15,16)$. Bound into the collagen in SIS are also glyco-proteins such as fibronectin (17); a general adhesion molecule that causes basement membrane assembly and attachment of epidermal cells, fibroblasts, endothelial cells $(18,19)$, and laminin (18); a linker molecule that joins collagen to proteoglycans and promotes endothelial cell adhesion and growth $(15,16)$. Glycosaminoglycans (GAGs) in the SIS have functional roles, such as organizing collagen deposition, stimulating angiogenesis and initiating cell differentiation (reviewed in [20]). Examples of GAGs found in SIS are heparin (which stimulates angiogenesis, potentiates both epidermal growth factor (EGF) and platelet derived growth factor (PDGF)-induced fibroblast differentiation), hylauronic acid (sequesters transforming growth factor beta (TGF- $\beta$ ) into the extracellular matrix), chondroitin sulfate (increases proteoglycan synthesis), and dermatan (interacts with TGF- $\beta 1$ and may control tissue remodeling).

\section{ECM Growth Factors Favor Cell Ingrowth}

ECM appears to maintain functioning growth factors even in sterilized products. These growth fac-

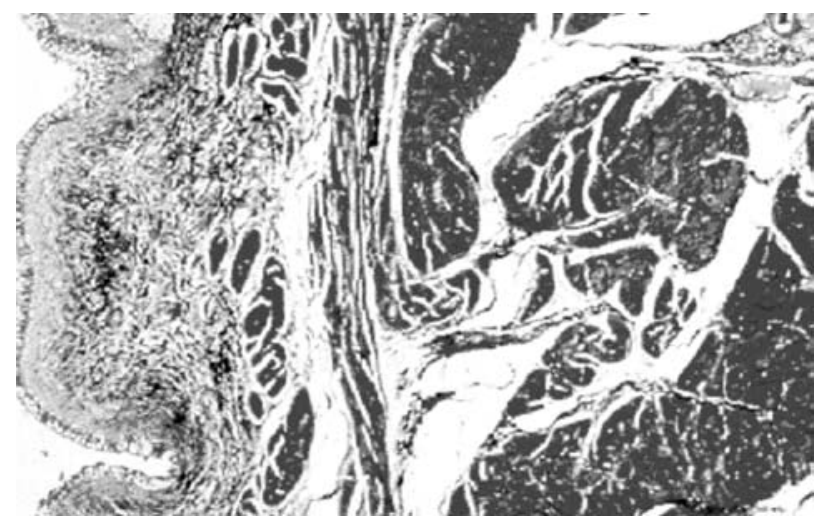

Figure 1 - Photomicrograph of SIS implanted in dog bladder as an augmentation cystoplasty. Masson's trichrome stain, 13 months after implantation. (Photomicrograph kindly provided by Dr. Steven Badylak.) 
tors promote tissue ingrowth and are likely one reason robust neovascularization of ECM grafts can be seen within only 3 days of implantation. Growth factors detectible in SIS include basic fibroblast growth factor (bFGF-2) (21), vascular endothelial growth factor (VEGF) $(21,22), \mathrm{TGF} \alpha$, and TGF $\beta$. The role of these compounds varies, but all have functions that might promote active ingrowth.

\section{ECM IS STRONG, AND THEN GETS STRONGER}

In the dry state, ECM in the form of SIS is brittle and sutures will tear through it. However, when reconstituted in saline for 5 minutes, it becomes quite strong and even $0.1 \mathrm{~mm}$ single layer SIS is difficult to tear. The breaking point of SIS can be compared to some known materials to give a sense of its strength: SIS 3.4 foot/pounds, polypropylene (Prolene ${ }^{\mathrm{TM}}$ ) suture 5 foot/pounds, polyglactin (Vicryl ${ }^{\mathrm{TM}}$ or Dexon ${ }^{\mathrm{TM}}$ ) suture 8 foot/pounds, cadaver fascia lata 5.6 foot/ pounds. SIS has an added benefit over these stronger items, however, in that it tends to stretch under force instead of breaking (23).

Although ECM starts out strong, it appears to get even stronger after implantation. A concept known as "Davis' Law" states that soft tissue heals more strongly along the plane in which it is stressed (24). This principal allows stronger healing of SIS grafts (25): one study of an SIS aorta graft shows it to be 3 times stronger after 3 months than when first implanted (25). A study of SIS replacing the canine abdominal wall is about 5 times stronger than the native abdominal wall (26).

\section{ECM IS IMMUNOCOMPATABLE}

ECM causes little detectible experimental immune reaction when implanted. Firstly, it is avascular, so hyper-acute rejection cannot occur. It is acellular, so it has a paucity of antigens that might cause hypersensitivity. In fact, experimental studies have shown no clinical or histologic evidence of immediate or delayed rejection to SIS (11). Rabbits implanted with SIS show no signs of antibody production to their major components (27). Even complement activation, which is a very nonspecific immune response, is absent (11). Some researchers have described a self-limited early acute inflammatory response which is largely resolved by day 10 consisting of polymorphonucleocyte (PMN) infiltration followed by modest monocyte infiltration (11). Interestingly, there is evidence that unknown factors in SIS actually inhibit local immune response by suppressing Helper T cells through interfering with local interferon-gamma expression (11). This theoretical lack of immunological response has not always been found clinically: 8-ply SIS marketed as Stratasis ${ }^{\circledR}$ has induced localized inflammation in about $50 \%$ of patients (28).

\section{PREPARATION OF ECM}

To prepare SIS, pig jejunum is processed by mechanically removing the mucosa, muscularis externa and serosa. The remaining SIS tissue represents submucosa and basal layers of mucosa. During processing, SIS is defatted, its cells destroyed with paracetic acid, and freeze-dried (18). SIS is not crosslinked, which tends to better preserve its handling characteristics (29). There is some experimental evidence that dehydrating the SIS results in less aggressive tissue ingrowth experimentally, but the significance of this is unknown (30), and SIS ingrowth appears to be intact despite this processing step. The final SIS product is $0.2-0.1 \mathrm{~mm}$ thick and has the appearance and handling characteristics of cellophane. Because SIS is a natural product, it has an interesting characteristic: Sis is 4 times more permeable to liquids in one direction (serosal to mucosal) than the other (31). The clinical implications of this are unknown.

Not all commercially available products are identically processed. Pelvicol ${ }^{\mathrm{TM}}$ porcine dermis, for instance, is mildly cross-linked with HMDI, gamma sterilized, and not freeze-dried. FortaPerm ${ }^{\mathrm{TM}}$ and FortaGen ${ }^{\mathrm{TM}}$ material is mildly cross-linked with EDC, gamma sterilized.

\section{AVAILABLE PRODUCTS}

It must be emphasized that although there are several tissue replacement products on the market, 
most are not similar to SIS in that they are not designed to allow replacement by host tissue. Most other commercially available products are strongly crosslinked, designed to last indefinitely (as apposed to being remodeled by target tissue), and are intended for limited use as pubovaginal slings or abdominal hernia bolsters. Nonetheless, all these products are described here in order to give a complete reckoning of the available armamentarium.

\section{Human Dermis}

The predominant acellular matrix grafts made from human cadaver tissue are Repliform ${ }^{\mathrm{TM}}$ (Microvasive; Boston, Massachusetts; USA) and Alloderm ${ }^{\mathrm{TM}}$ (LifeCell; Branchburg, New Jersey; USA), both of which are processed human dermis. Repliform ${ }^{\mathrm{TM}}$ comes in thin and thick forms and is used as a pubovaginal sling material and Alloderm ${ }^{\mathrm{TM}}$ as a skin substitute. Repliform ${ }^{\mathrm{TM}}$ is freeze-dried. It is unknown if these materials can be used as urologic (bladder, urethral, ureter) substitutes like SIS could be. The company claims preservation of collagen, elastin, and proteoglycans in these materials, but no published data is available.

\section{Porcine Dermis}

Pelvicol $^{\mathrm{TM}}$ is porcine skin that is gamma sterilized and lightly crosslinked. It appears that its permanence and thickness (it comes in $.75 \mathrm{~mm}$ and 1.5 $\mathrm{mm}$ thickness - much thicker than SIS) might make it useful for pubovaginal slings only.

\section{Small Intestine Submucosa - SIS}

SIS is available as a single layer (Surgisis ${ }^{\mathrm{TM}}$ ), a 4 layer product (Surgisis-ES ${ }^{\mathrm{TM}}$ and Stratasis ${ }^{\mathrm{TM}}$ ), an 8-layer product for slings (Stratasis $®$ ), and as a 10 layer graft for abdominal (ventral) hernia repair. Another commercially-available abdominal hernia repair product called GraftPatch ${ }^{\mathrm{TM}}$ (Organogenesis Inc., Canton Massachusetts) is a 6-layer SIS that is crosslinked for relative permanence (32).

\section{Other ECMs}

Acellular matrix grafts that can be made from the bladder, urethra or ureter have been well characterized in research studies, but are not yet commer- cially available. This material is often called "bladder acellular matrix graft" and given the acronym BAMG. However, in many of the research articles the graft is taken from different source tissues, making this moniker inaccurate. Acellular matrix grafts seem to have similar characteristics to porcine SIS (33). Specifically, an acellular matrix graft of rabbit ureter placed into a rabbit urethra model allowed regrowth of endothelial, muscle and blood vessels (34), just as SIS does (35). There is clear evidence that the source of the acellular matrix graft affects the quality of subsequent tissue ingrowth (36), but it is too early to determine which is the best donor animal for urologic uses. Finally, a commercial ECM product made from porcine bladder is currently available for the veterinary market and may be available for human use in the future ("UBM"; Acell Corporation; Jessup, Maryland).

\section{SURGICAL USES}

\section{Pubovaginal Sling}

SIS (4 layer Stratasis ${ }^{\mathrm{TM}}$, which generally comes in long strips designed for use as a sling) has been used successfully as a pubovaginal sling in 87 humans using a bone-anchoring technique. Generally, results were good: 4/87 (5\%) patients did not get relief from their stress incontinence, but 2 of these were due to displaced bone anchors. There were no infections, erosions or graft failures (4). Bovine pericardium has also been used successfully to relieve stress incontinence, with $21 / 22$ patients in one study achieving correction of their urinary incontinence (37). Preliminary studies indicate that Pelvicol ${ }^{\mathrm{TM}}$, too, can be used as a pubovaginal sling using a minimally invasive technique in humans (38), but long term data is lacking. 4 layer SurgisisESTM SIS comes in sheets and can be cut to fit any size (the largest piece is $7 \times 20 \mathrm{~cm}$ ) and large "T" shaped slings can be fashioned to provide both cystocele (posterior) repair and pubovaginal urethral sling (anterior) if desired.

\section{Hypospadias}

Human cadaver bladder acellular matrix grafts were successfully used in hypospadias repairs ranging from $5-15 \mathrm{~cm}$ in length in a small number (4) 
of patients. All 4 patients had a patent urethra at 22 months and 1 patient with a very long $15 \mathrm{~cm}$ defect had a complicating fistula (39).

\section{Urethroplasty}

A variety of acellular matrix grafts have been used successfully as experimental urethral onlay grafts. A porcine bladder acellular matrix has been used successfully in an experimental rabbit urethroplasty model, but this was fresh product that may not be the same as commercial-grade product. The urethral caliber was maintained over the study interval, early ingrowth of blood vessels was documented and a healthy transitional cell layer with smooth muscle replaced the graft over time (40). Another interesting study used acellular grafts made from rabbit aorta to bridge long urethral gaps in rabbits, and these formed a patent neourethra (34). Acellular matrix grafts made from rabbit or dog urethra were also used successfully to replace a $1 \mathrm{~cm}$ portion of rabbit urethra (41). In this study, there were no fistulae, and the rabbits had both normal urethrograms and urethral pressure profiles. At six months, the urethral grafts had abundant smooth muscle, although they had less muscle than native rabbit urethra. Recently, the successful use of tubularized collagen matrices in rabbit urethral replacement has been reported (42). Finally, SIS was compared to a preputial skin graft in a rabbit urethroplasty model (43). SIS seemed to work better than the skin, and had the added benefit of regenerating epithelium and smooth muscle into the graft.

Little human data is available about the use of these grafts for urethral reconstruction. Twentyeight patients were treated in one study, most with long strictures. The success rate was $24 / 28$ (86\%) at minimum 36 months follow up, while 1 patient out of $28(4 \%)$ had a fistula which closed spontaneously (44). There is some theoretical evidence from research using acellular bladder grafts that protection from urinary extravasation is important for decreasing early inflammation (45), so when used in the urethra it may be prudent to provide an extended period of urinary drainage until regrowth of epithelium and some underlying muscle is complete.

\section{Bladder Replacement/Augmentation}

Bladder augmentation with acellular grafts has the most animal data support of all, yet experts still feel that it will not ultimately be appropriate for human use. A longitudinal study of SIS implanted into a dog bladder, Badylak et al. (46) showed that the augmentation graft re-grew vessels, epithelium and a continuous basement membrane by 4 weeks time. By 8 weeks, there were bundles of smooth muscle and collagen and inflammatory cells were largely absent. By 12 weeks, there was parallel orientation of smooth muscle cells and the complete degradation of SIS, leaving a functioning bladder. Others have confirmed these results and reported that bladder-augmented dogs showed stable preservation of bladder volume over time (47). SIS has also been successful in other animals such as mini-pigs (48). However, the SIS patches seem to contract to $58 \%$ of their original size, so augmentations using SIS should be greatly upsized to compensate for this shrinkage (48). SIS in rats created a bladder that was indistinguishable from a native bladder (49) with the surprising finding that the grafts had become normally innervated. Although these initial positive results in animals have been widely reported, others have described disappointing preliminary results using SIS in both dog and porcine models $(50,51)$.

Bladder acellular matrix grafts (BAMG) using rat (52), dog, hamster and rabbit bladders were placed into rats in an augmentation cystoplasty model (53). There was epithelialization, angiogenesis, detrusor muscle proliferation and regeneration of nerve fibers. In a similar rat model, the bladder volume and compliance were consistent with the formation of a low-pressure urinary reservoir (54). These regenerated bladders had functional contractile ability consistent with the findings in small animals that nerves regenerated into the graft (55). Dog BAMG put into dogs confirmed the possibility of successful bladder augmentation in larger animals (56). All 4 layers (mucosa, muscularis mucosa, detrusor and serosa) were present, as were nerves. Finally, in one swine study, BAMG re-capitulated the native bladder as expected but shrunk $25 \%$ from its original size in 12 weeks (57). Stratasis ${ }^{\mathrm{TM}}$ placed in pigs using a laparoscopic technique proved that a leak-free bladder augmenta- 
tion could be achieved, although the study had small numbers (58).

Human data is largely lacking. Permacol ${ }^{\mathrm{TM}}$ (a.k.a. Pelvicol ${ }^{\mathrm{TM}}$ ) has been used in 5 patients as a bladder augmentation but preliminary data has been presented only in abstract form. It appears there were no early complications in this small abstract series (5).

\section{Partial Nephrectomy}

Preliminary reports indicate that SIS may be a helpful adjunct in closing the parenchymal defect after partial nephrectomy in humans (6). Theoretically, large sheets of SIS could be used to encase and repair kidneys after partial nephrectomy or even renal injury. Severely injured, even shattered kidneys, might be repaired with SIS just as has been done with polyglactin (Vicryl ${ }^{\mathrm{TM}}$ or Dexon ${ }^{\mathrm{TM}}$ ) mesh in the past (59). Further data will be needed to further validate this use of ECM.

\section{Peyronie's Disease}

A significant body of literature focusing on the use of acellular matrix grafts in urologic reconstruction of Peyronie's disease in both humans and animal models has emerged. Both SIS and rabbit tunica albuginea derived acellular matrix grafts have been used for successful correction of Peyronie's in rabbit models $(60,61)$. In humans, both bovine pericardium and SIS have been used successfully as a corporal patch after incision of Peyronie's plaque $(5,62)$ as well as for reconstruction of tunical deficiencies following penile prosthesis placement (63). Permacol $^{\mathrm{TM}}$ (a.k.a. Pelvicol ${ }^{\mathrm{TM}}$ ) has been used in 5 patients as a Peyronie's patch with good but preliminary results (9). Finally, a single case report has shown the use of cadaveric tensor fascia lata in cavernosal reconstruction following partial penectomy with satisfactory results (64). In our hands, 3 of 4 patients grafted with single or double layer SIS had severe recurrence of penile deformity, and we continue to approach its use with caution.

\section{Abdominal Hernia \\ Multi-layered SIS patches have proven ex- perimentally effective at repairing ventral hernia de-}

fects, although human studies are lacking. GraftPatch $^{\mathrm{TM}}$ (Organogenesis Inc., Canton Massachusetts), a 6-layer SIS graft, repaired experimentallycreated abdominal wall defects in rabbits with few adhesions (27). 8-ply SIS was used to repair experimentally-created abdominal hernias in dogs and rodents, with excellent preservation of strength over a 2-year follow up period $(26,65)$. When compared to repair with polypropylene (Prolene) mesh, the SIS has less inflammation, less foreign-body reaction, and far fewer intestinal adhesions (66).

\section{Ureteral Replacement}

Replacement of ureters with acellular grafts is the most controversial because some studies show it works and others show it fails. Rat ureter was successfully replaced with a ECM graft made of rat ureter with excellent recapitulation of ureteral tissue: epithelium, blood vessels, smooth muscle and even nerves were all present by 4 months (13). However, a criticism of this study is that the ureters were left stented for the duration of the study and it is unknown if the ureters would have stayed open after the stents were removed. Rabbit ureter was also successfully replaced with SIS grafts, which eventually recapitulated the 3 layers of the ureter (epithelium, muscle layer, serosa) and showed robust neovascularity (67). Replacement of swine ureter with SIS resulted in a widely patent re-growth of the missing portion with neovascularization, smooth muscle, epithelium, and scant foreign body reaction $(68,69)$. There is a single human case study where SIS was used to successfully reconstruct a stenosed uretero-neobladder stricture (70). More convincing human data are not yet available.

There are notable failures, however. When researchers at Washington University tried to replace a surgically-removed ureteric segment with a tubularized SIS segment using a laparoscopic technique, this method failed in 6 of 6 animals (48). A similar study of ureteric replacement with SIS in minipigs also failed (71). It is unknown what accounted for these failures, which stand out among the large number of SIS successes in a variety of target tissues reported in the literature. Ureteral reconstruction is notoriously difficult, and experiments using free fas- 
cial transplants, autologous veins, arterial grafts, skin grafts, freeze-dried ureter, and autologous ureter have also failed in the past (cited in ref 48).

A possible use for SIS in the ureter would be to bolster ureteral repairs after ureteroureterostomy or open ureteral re-implants. Experimentally, this has been shown to be successful when the first generations of implantable collagen membranes were used to bolster ureteral repairs in rabbits (72).

\section{Injectable SIS Bulking Agent}

Although this review is not meant to explore the field of injectable bulking agents in urology, it is notable that a paste made from SIS has been developed. Preliminary studies in dogs showed that the injected paste induced smooth muscle regeneration with long-term preservation of $25 \%$ of the original injection volume (73).

\section{Urethral Coverage Layer}

SIS can be used as an "extra layer" in urethral surgery. Rabbit models have shown successful proof of this concept (74) and it may be particularly useful in long urethral suture lines, such as during long hypospadias repair, second stage Johanson urethroplasty or penile urethroplasty in multiply-operated patients.

\section{THE FUTURE}

Techniques in tissue engineering also continue to improve and several notable potential improvements in techniques show promise.

\section{Cell-seeded Acellular Matrix}

One potential improvement in existing acellular graft material is achieved by pre-seeding the grafts with the patient's own urothelial cells. These cells can be harvested from the host (usually by bladder or urethral biopsy), cell cultured and then seeded into acellular matrix (75). Where this approach was attempted using both bladder urothelial cells and bladder smooth muscle cells seeded onto an acellular collagen matrix patch in an animal augmentation cystoplasty model (45), bladder capacity was significantly improved when compared to unseeded acellular collagen. Subsequent studies using bladder replacement in dogs with cells seeded onto a biodegradable cell free polymer were equally successful (76). Clinical success has already been achieved using this approach to engineer skin grafts (77). Recently, two ambitious reports showed that it was possible to seed bladder urothelium and smooth muscle onto an SIS matrix, an approach which improved the quantity of smooth muscle in a bladder graft when compared to SIS alone (12). This innovation has the potential to be the next "state of the art" in the field.

\section{Modification of Acellular Grafts to Promote Ingrowth}

Special preparation of acellular grafts using gene therapy techniques might also improve the quality of implantable materials in the future. Theoretically, seeded cells as described above could be transfected with desirable genes in order to reverse existing bladder or urethral disease or promote healthy tissue ingrowth (75). This remains theoretical today. Acellular grafts might also be modified by adding desirable matrix molecules to improve healthy tissue ingrowth. Glycosaminoglycans such as heparin (78) and chondroitin (79) have been successfully added to collagen matrices to successfully improve neoangiogenesis.

\section{CONCLUSIONS}

Much work has been done to validate the use of acellular matrix grafts in urology, but most of it remains experimental or only of preliminary clinical nature. More clinical work must be done before most of us are fully comfortable with using these materials everyday. The best validated human studies confirm success when SIS is used as a pubovaginal sling, or extra bolstering layers in ureteral or urethral repairs, although recent problems with inflammation after 8ply pubovaginal sling and failures after 1- and 4-ply SIS repair of Peyronie's disease underscore the need for research before wide adoption. Preliminary data is mixed concerning the potential for an SIS urethral patch graft, and more data is needed before extended uses such as bladder augmentation and ureteral re- 
placement are contemplated. The more distant future of ECMs in urology likely will include cell-seeded grafts, with the eventual hope of "off the shelf" replacement materials. Until that day arrives, ECMs fulfill only some of the requirements for the reconstructive urologist.

\section{REFERENCES}

1. Badylak SF, Lantz GC, Coffey A, Geddes LA: Small intestinal submucosa as a large diameter vascular graft in the dog. J Surg Res. 1989; 47: 74-80.

2. Badylak SF: Small intestinal submucosa (SIS): A biomaterial conductive to smart tissue remodeling, in Bell E: Tissue Engineering: Current Perspectives. Boston, Birkhauser, 1993, pp. 179-189.

3. Kassaby E, Yoo JJ, Retik AB, Atala A: A novel inert collagen matrix for urethral stricture repair. J Urol. 2000; 163: 70.

4. Rutner AB, Levine SR, Schmaelzle JF: Porcine small intestine submucosa implantation for pubovaginal slings: Results and conclusions after two years in eighty-seven female patients. Society for Urology and Engineering. 16th Annual Meeting. Anaheim, CA, 2001.

5. Knoll LD: Use of porcine small intestinal submucosal graft in the surgical management of Peyronie's disease. Urology. 2001; 57: 753-7.

6. Corey OCR, Patel RV, Laven BA,Steinberg GD: The use of small intestinal submucosa (SIS) to improve outcomes following partial nephrectomy. North Central Section American Urologic Association. Chicago, IL, 2002.

7. Speakman MJ: Bladder augmentation cystoplasty with a novel collagen membrane. BJU Int. 2000; 85 (Supl. 5): 2-3.

8. Barrington JW, Edwards G, Arunkalaivanan AS, Swart M: The use of porcine dermal implant in a minimally invasive pubovaginal sling procedure for genuine stress incontinence. BJU Int. 2002; 90: 224-7.

9. Lloyd SN, Hetherington J: Plaque excision and Permacol grafting for Peyronie's disease. BJU Int. 2000; 85 (Supl. 5): 16.

10. Harper C: Permacol: clinical experience with a new biomaterial. Hosp Med. 2001; 62: 90-5.

11. Allman AJ, McPherson TB, Badylak SF, Merrill LC, Kallakury B, Sheehan C, et al.: Xenogeneic extracellular matrix grafts elicit a TH2-restricted immune response. Transplantation. 2001; 71: 1631-40.
12. Zhang Y, Kropp BP, Moore P, Cowan R, Furness PD 3rd, Kolligian ME, et al.: Coculture of bladder urothelial and smooth muscle cells on small intestinal submucosa: potential applications for tissue engineering technology. J Urol. 2000; 164: 928-34; discussion 934-5.

13. Dahms SE, Piechota HJ, Nunes L, Dahiya R, Lue TF, Tanagho EA: Free ureteral replacement in rats: regeneration of ureteral wall components in the acellular matrix graft. Urology. 1997; 50: 818-25.

14. Vaught JD, Kropp BP, Sawyer BD, Rippy MK, Badylak SF, Shannon HE, et al.: Detrusor regeneration in the rat using porcine small intestinal submucosal grafts: functional innervation and receptor expression. J Urol. 1996; 155: 374-8.

15. Macarak EJ, Howard PS: Adhesion of endothelial cells to extracellular matrix proteins. J Cell Physiol. 1983; 116: 76-86.

16. Herbst TJ, McCarthy JB, Tsilibary EC, Furcht LT: Differential effects of laminin, intact type IV collagen, and specific domains of type IV collagen on endothelial cell adhesion and migration. J Cell Biol. 1988; 106: 1365-73.

17. McPherson TB and Badylak SF: Characterization of fibronectin derived from porcine small intestinal submucosa. Tissue Engineering. 1998; 4: 75-83.

18. Badylak S, Liang A, Record R, Tullius R, Hodde J: Endothelial cell adherence to small intestinal submucosa: an acellular bioscaffold. Biomaterials. 1999; 20: 2257-63.

19. Dejana E, Colella S, Languino LR, Balconi G, Corbascio GC, Marchisio PC: Fibrinogen induces adhesion, spreading, and microfilament organization of human endothelial cells in vitro. J Cell Biol. 1987; 104: 1403-11.

20. Hodde J, Badylak S, Brightman A, Voytik-Harbin S: Glycosaminoglycan content of small intestinal submucosa: A bioscaffold for tissue replacement. Tissue Engineering. 1996; 2: 209-17.

21. Voytik-Harbin SL, Brightman AO, Kraine MR, Waisner B, Badylak SF: Identification of extractable growth factors from small intestinal submucosa. J Cell Biochem. 1997; 67: 478-91.

22. Hodde JP, Record RD, Liang HA, Badylak SF: Vascular endothelial growth factor in porcine-derived extracellular matrix. Endothelium. 2001; 8: 11-24.

23. Kubricht WS 3rd, Williams BJ, Eastham JA, Venable DD: Tensile strength of cadaveric fascia lata compared to small intestinal submucosa using suture pull through analysis. J Urol. 2001; 165: 486-90. 
24. Tippett SR, Voight ML: Functional Progressions for Sport Rehabilitation. Champlain, IL, Human Kinetics, 1995.

25. Hiles MC, Badylak SF, Lantz GC, Kokini K, Geddes LA, Morff RJ: Mechanical properties of xenogeneic small-intestinal submucosa when used as an aortic graft in the dog. J Biomed Mater Res. 1995; 29: 88391.

26. Badylak S, Morff R, Tullius R: The use of SIS as a scaffold for abdominal hernia repair: Second SIS Symposium. Orlando, FL, 1998, pp. 48-49.

27. Abraham GA, Murray J, Billiar K, Sullivan SJ: Evaluation of the porcine intestinal collagen layer as a biomaterial. J Biomed Mater Res. 2000; 51: 442-52.

28. Ho KL, Witte MN, Bird ET: 8-ply small intestinal submucosa tension-free sling: spectrum of postoperative inflammation. J Urol. 2004; 171: 268-71.

29. Khor E: Methods for the treatment of collagenous tissues for bioprostheses. Biomaterials. 1997; 18: 95105.

30. Lindberg K, Badylak SF: Porcine small intestinal submucosa (SIS): a bioscaffold supporting in vitro primary human epidermal cell differentiation and synthesis of basement membrane proteins. Burns. 2001; 27 : 254-66.

31. Ferrand BK, Kokini K, Badylak SF, Geddes LA, Hiles MC, Morff RJ: Directional porosity of porcine smallintestinal submucosa. J Biomed Mater Res. 1993; 27 : 1235-41.

32. Gloeckner DC, Sacks MS, Billiar KL, Bachrach N: Mechanical evaluation and design of a multilayered collagenous repair biomaterial. J Biomed Mater Res. 2000; 52: 365-73.

33. Sievert KD, Tanagho EA: Organ-specific acellular matrix for reconstruction of the urinary tract. World $\mathbf{J}$ Urol. 2000; 18: 19-25.

34. Parnigotto PP, Gamba PG, Conconi MT, Midrio P: Experimental defect in rabbit urethra repaired with acellular aortic matrix. Urol Res. 2000; 28: 46-51.

35. Sievert KD, Bakircioglu ME, Nunes L, Tu R, Dahiya $\mathrm{R}$, Tanagho EA: Homologous acellular matrix graft for urethral reconstruction in the rabbit: histological and functional evaluation. J Urol. 2000; 163: 195865.

36. Wefer J, Sekido N, Sievert KD, Schlote N, Nunes L, Dahiya R, et al.: Homologous acellular matrix graft for vaginal repair in rats: a pilot study for a new reconstructive approach. World J Urol. 2002; 20: 260-3.

37. Pelosi MA 2nd, Pelosi MA 3rd, Pelekanos M: The YAMA UroPatch sling for treatment of female stress urinary incontinence: a pilot study. J Laparoendosc Adv Surg Tech A. 2002; 12: 27-33.

38. Edwards G, Barrington J: The use of Pelvicol in a minimally invasive pubovaginal sling procedure: 25 th Annual Meeting of the International Urogynecological Association. Rome, Italy, 2000, pp. IDP49.

39. Atala A, Guzman L, Retik AB: A novel inert collagen matrix for hypospadias repair. J Urol. 1999; 162: 1148-51.

40. Chen F, Yoo JJ, Atala A: Acellular collagen matrix as a possible "off the shelf" biomaterial for urethral repair. Urology. 1999; 54: 407-10.

41. Sievert KD, Wefer J, Bakircioglu ME, Nunes L, Dahiya R, Tanagho EA: Heterologous acellular matrix graft for reconstruction of the rabbit urethra: histological and functional evaluation. J Urol. 2001; 165: 2096102.

42. De Filippo RE, Yoo JJ, Atala A: Urethral replacement using cell seeded tubularized collagen matrices. J Urol. 2002; 168: 1789-92; discussion 1792-3.

43. Kropp BP, Ludlow JK, Spicer D, Rippy MK, Badylak SF, Adams MC, et al.: Rabbit urethral regeneration using small intestinal submucosa onlay grafts. Urology. 1998; 52: 138-42.

44. El-Kassaby AW, Retik AB, Yoo JJ, Atala A: Urethral stricture repair with an off-the-shelf collagen matrix. J Urol. 2003; 169: 170-3; discussion 173.

45. Yoo JJ, Meng J, Oberpenning F, Atala A: Bladder augmentation using allogenic bladder submucosa seeded with cells. Urology. 1998; 51: 221-5.

46. Badylak SF, Record R, Lindberg K, Hodde J, Park K: Small intestinal submucosa: a substrate for in vitro cell growth. J Biomater Sci Polym Ed. 1998; 9: 863-78.

47. Kropp BP, Rippy MK, Badylak SF, Adams MC, Keating MA, Rink RC, et al.: Regenerative urinary bladder augmentation using small intestinal submucosa: urodynamic and histopathologic assessment in long-term canine bladder augmentations. J Urol. 1996; 155: 2098-104.

48. Shalhav AL, Elbahnasy AM, Bercowsky E, Kovacs G, Brewer A, Maxwell KL, et al.: Laparoscopic replacement of urinary tract segments using biodegradable materials in a large-animal model. J Endourol. 1999; 3: 241-4.

49. Kropp BP, Eppley BL, Prevel CD, Rippy MK, Harruff RC, Badylak SF, et al.: Experimental assessment of small intestinal submucosa as a bladder wall substitute. Urology. 1995; 46: 396-400.

50. Patterson RF, Shalhav AL, Barret E, Cheng L, Ligeman JE, Sanghvi N: Multilayered small intestinal submu- 
cosa inferior to autologous bowel for laparoscopic bladder augmentation at one year follow up: North Central Section American Urologic Association. Chicago, IL, 2002, pp 109.

51. Pope JC 4th, Davis MM, Smith ER Jr., Walsh MJ, Ellison PK, Rink RC, et al.: The ontogeny of canine small intestinal submucosa regenerated bladder. J Urol. 1997; 158: 1105-10.

52. Wefer J, Sievert KD, Schlote N, Wefer AE, Nunes L, Dahiya R, et al.: Time dependent smooth muscle regeneration and maturation in a bladder acellular matrix graft: histological studies and in vivo functional evaluation. J Urol. 2001; 165: 1755-9.

53. Cayan S, Chermansky C, Schlote N, Sekido N, Nunes L, Dahiya R, et al.: The bladder acellular matrix graft in a rat chemical cystitis model: functional and histologic evaluation. J Urol. 2002; 168: 798-804.

54. Piechota HJ, Gleason CA, Dahms SE, Dahiya R, Nunes LS, Lue TF, et al.: Bladder acellular matrix graft: in vivo functional properties of the regenerated rat bladder. Urol Res. 1999; 27: 206-13.

55. Piechota HJ, Dahms SE, Nunes LS, Dahiya R, Lue $\mathrm{TF}$, Tanagho EA: In vitro functional properties of the rat bladder regenerated by the bladder acellular matrix graft. J Urol. 1998; 159: 1717-24.

56. Probst M, Piechota HJ, Dahiya R, Tanagho EA: Homologous bladder augmentation in dog with the bladder acellular matrix graft. BJU Int. 2000; 85: 362-71.

57. Reddy PP, Barrieras DJ, Wilson G, Bagli DJ, McLorie GA, Khoury AE, et al.: Regeneration of functional bladder substitutes using large segment acellular matrix allografts in a porcine model. J Urol. 2000; 164: 936-41.

58. Calvano CJ, Moran ME, Parekh A, Desai PJ, Cisek LJ: Laparoscopic augmentation cystoplasty using the novel biomaterial Surgisis: small-intestinal submucosa. J Endourol. 2000; 14: 213-7.

59. Mounzer AM, McAninch JW, Schmidt RA: Polyglycolic acid mesh in repair of renal injury. Urology. 1986; 28: 127-30.

60. Monga M, Cosgrove D, Zupkas P, Jain A, Kasyan A, Wilkes N, et al.: Small intestinal submucosa as a tunica albuginea graft material. J Urol. 2002; 168: 121521.

61. Wefer J, Schlote N, Sekido N, Sievert KD, Wefer AE, Nunes L, et al.: Tunica albuginea acellular matrix graft for penile reconstruction in the rabbit: a model for treating Peyronie's disease. BJU Int. 2002; 90: 326-31.

62. Egydio PH, Lucon AM, Arap S: Treatment of Peyronie's disease by incomplete circumferential in- cision of the tunica albuginea and plaque with bovine pericardium graft. Urology. 2002; 59: 570-4.

63. Knoll LD: Use of porcine small intestinal submucosal graft in the surgical management of tunical deficiencies with penile prosthetic surgery. Urology. 2002; 59: 758-61.

64. Christopher N, Arya M, Brown RS, Payne HA, Woodhouse CR, Ralph DJ: Penile preservation in squamous cell carcinoma of the bulbomembranous urethra. BJU Int. 2002; 89: 464-5.

65. Badylak S, Kokini K, Tullius B, Simmons-Byrd A, Morff R: Morphologic study of small intestinal submucosa as a body wall repair device. J Surg Res. 2002; 103: 190-202.

66. Clarke KM, Lantz GC, Salisbury SK, Badylak SF, Hiles MC, Voytik SL: Intestine submucosa and polypropylene mesh for abdominal wall repair in dogs. J Surg Res. 1996; 60: 107-14.

67. Jackson OF: Urolithiasis and experimental urethral obstruction in the cat. J Physiol. 1969; 201: 97-8P.

68. Li BZ: Long-term effect of the pull-through operation in traumatic posterior urethral stricture. Zhonghua Wai Ke Za Zhi. 1984; 22: 368-9.

69. Smith TG 3rd, Gettman M, Lindberg G, Napper C, Pearle MS, Cadeddu JA: Ureteral replacement using porcine small intestine submucosa in a porcine model. Urology. 2002; 60: 931-4.

70. O'Connor RC, Patel RV, Steinberg GD: Successful repair of a uretero-neobladder stricture using porcine small intestine submucosa. J Urol. 2001; 165: 1995.

71. Xie H, Shaffer BS, Wadia Y, Gregory KW: Use of reconstructed small intestine submucosa for urinary tract replacement. Asaio J. 2000; 46: 268-72.

72. Scott R, Baraza R, Gorham SD, McGregor I, French DA: Assessment of collagen film for use in urinary tract surgery. Br J Urol. 1986; 58: 203-7.

73. Furness PD 3rd, Kolligian ME, Lang SJ, Kaplan WE, Kropp BP, Cheng EY: Injectable small intestinal submucosa: preliminary evaluation for use in endoscopic urological surgery. J Urol. 2000; 164: 1680-5.

74. Grossklaus DJ, Shappell SB, Adams MC, Brock JW 3rd, Pope JC 4th: Small intestinal submucosa as a urethral coverage layer. J Urol. 2001; 166: 636-9.

75. Atala A: Construction of artificial organs and tissues using autologous cells. AUA Update Series. 2000; 19: 122-8.

76. Oberpenning F, Meng J, Yoo JJ, Atala A: De novo reconstitution of a functional mammalian urinary bladder by tissue engineering. Nat Biotechnol. 1999; 17 : 149-55. 
77. Casasco A, Casasco M, Zerbinati N, Icaro Cornaglia A, Calligaro A: Cell proliferation and differentiation in a model of human skin equivalent. Anat Rec. 2001; 264: 261-72.

78. Noe HN, Dale GA: Evaluation of children with meatal stenosis. J Urol. 1975; 114: 455-6.
79. Pieper JS, van Wachem PB, van Luyn MJA, Brouwer LA, Hafmans T, Veerkamp JH, et al.: Attachment of glycosaminoglycans to collagenous matrices modulates the tissue response in rats. Biomaterials. 2000; 21 : 1689-99.

\author{
Correspondence address: \\ Dr. Richard A. Santucci \\ 4160, John R, Suite 1017 \\ Detroit, MI 48167, USA \\ Fax: + 313-745-0464 \\ E-mail:rsantucc@med.wayne.edu
}


This article has received corrections in agreement with the ERRATUM published in Volume 31 Number 4. 